Удк 631.527:581.2(092)

\title{
ПАМ'ЯТІ ВОЛОДИМИРА ФЕДОРОВИЧА ПЕРЕСИПКІНА
}

А.В. Андрющенко, кандидат біологічних наук Український інститут експертизи сортів рослин

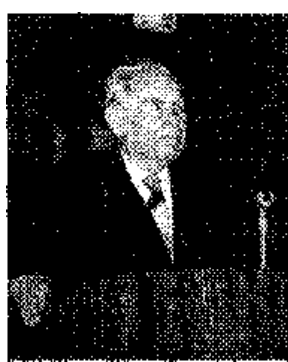

Минуло два роки відтоді, як пішов від нас назавжди Пересипкін. Ми - його учні, ще не усвідомили всієї глибини втрати, але зрозуміли, що пішла Людина з великої літери, академік, заслужений діяч сільськогосподарської науки, державна людина, вчитель. Володимир Федорович прожив тривале і насичене подіями життя: пройшов важкими дорогами Великої Вітчизняної війни, обіймав посаду заступника Міністра сільського господарства України,

ректора Української сільськогосподарської академії, був першим Головою Південного відділення ВАСГНІЛ. Близько 200 кандидатів і докторів наук із спеціальності фотопатології і захисту рослин виховано Володимиром Федоровичем. Його ім'я, як фітопатологаселекціонера, стоїть поряд $з$ іменами таких корифеїв, як Страхов і Гешелє.

Ми завжди відчували його присутність. Він був з нами, хоча роками не бачились. А зараз ми начебто посиротіли. Ми вже ніколи не почуємо його дружньо-наставницького і принципового голосу, наповненого емоціями, аргументами і фрактами, очікуваними або неочікуваними критичним зауваженнями.

За понад 40 років безпосереднього знайомства 3 Володимиром Федоровичем велике й щире спасибі долі.

Під час навчання в УСГА (1963-1968 рр.) він був моїм ректором і завідувачем кафредрою фітопатології, на якій я, студент агрофраку, підробляв лаборантом. Завдяки цьому, у мене було подвійне товариство - агрономів і захисників рослин. Я залюбки вчився фрітопатології, що і було підставою до вступу до аспірантури при кафредрі під керівництвом В.Ф. Пересипкіна. У 1970 р. його призначають на посаду Голови Південного відділення ВАСГНІЛ. На Володимира Федоровича лягла організація Відділення, яке розташовувалося на вул. Леніна, 46. Тут уже не до керівництва аспірантами. Але це для інших, а не для Пересипкіна В.Ф. Він знаходив і час, і місце. Для цього використовувалось усе доступне: хвилинне затишшя між нескінченими телефонними дзвінками з усієї 
України, регіонів Молдови і Росії; між господарчими справами, численними відрядженнями, місцевими переміщеннями у службовій машині від вул. Леніна до ВДНГ, вокзалів, УСГА. і цього було досить, щоб зрозуміти проблему, навіть вирішити ії, попередити наступні й отримати чергові завдання.

Не зважаючи на перенавантаження, дефіцит часу, Володимир Федорович знаходив можливість, щоб відповісти на запрошення і відвідати студентське весілля чи взяти участь у відзначенні якоїсь події на кафедрі. Полюбляв на своїх днях народження бачити побільше своїх вихованців і на повну силу демонстрував свою гостинність, чемність, інтелігентність і гумор.

Таким ми його і запам'ятаємо на все життя і передамо світлу пам'ять про нього своїм онукам. 